\title{
Complementarity, rivalry and substitution in the governance of forests: learning from independent forest monitoring system in Cameroon
}

\author{
Aurelian Mbzibain $^{\mathrm{a}}$, Symphorien Ongolo \\ ${ }^{a}$ University of Wolverhampton, Centre for International Development and Training (CIDT); Telford TF2 \\ 9NT, UK +44 01902323 140. Email: a.mbzibain2@wlv.ac.uk \\ ${ }^{b}$ Chair of Forest and Nature Conservation Policy;Research Group Leader "Global Forestland Policy \& \\ Sustainability" University of Göttingen, Büsgenweg 3 - Office 2.10637077 Göttingen - Germany \\ E-mail: songolo@uni-goettingen.de
}

Corresponding author: Present Address: University of Wolverhampton, Centre for International

Development and Training (CIDT); Email: a.mbzibain2@wlv.ac.uk

\begin{abstract}
The consequence of state controlled forestry in Cameroon has been the overexploitation of forest resources often in conflict with local forest dependent communities and state conservation objectives. The failure of state controlled forestry to achieve sustainable forest management has led to the emergence of new network like arrangements amongst which is independent forest monitoring (IFM) by civil society. The aim of this paper is to scrutinize the factors which affect the effectiveness of IFM governance network in Cameroon. Our research focused on a case study of Cameroon, employing a governance network perspective. The main findings are that national civil society in Cameroon is playing a significant role in improving transparency in the forest sector and holding decision makers to account. The paper finds a shift from technical areas of forest monitoring to the monitoring of social obligations and the respect of community rights by private companies. An analysis of actors highlights a strong network of national NGOs with self-defined goals and strategies engaged in very fluid relationships with law enforcement agencies beyond traditional ministries of forests and wildlife characterised by a spectrum ranging from complementarity, substitution and rivalry. The lack of sustainable funding and weak capabilities of national NGOs to navigate these fluid relationships emerges as core constraints for network effectiveness. Accordingly, recommendations for effectiveness entail strategies for sustainable funding, capacity strengthening and network coordination to address current weaknesses but also to build trust and credibility of the governance network.
\end{abstract}

Keywords: independent forest monitoring, governance network, complementarity, substitution, rivalry 


\section{Introduction}

Forests provide a wide range of tangible and non-tangible goods and services from the local level to the planet (Byron and Arnold 1999, Garcia-Nieto et al. 2013). Tropical forests are host to the most important world's territorial biodiversity, and play a significant role in mitigating global climate change and contributing to soil and water conservation (Mulata et al. 2017). In addition these forests provide many other vital resources and habitats for forest-dependent people such as provision of arable lands, non-timber forest products, woodfuel, medicine, religious and cultural sites (FAO 2014). In Africa, the Congo Basin forests form the second largest block of rainforest in the world after the Amazon and span six forest-rich countries: Cameroon, the Central African Republic (CAR), the Democratic Republic of Congo (DRC), the Republic of Congo (RoC), Equatorial Guinea (EG), and Gabon. Estimates of the number of people who derive direct or indirect benefits from the world's forests in terms of employment, forest products, livelihoods and incomes stands at between 1 billion to 1.5 billion (Agrawal et al. 2013). Central African Forests provide direct subsistence services to over 60 million people who live within or near forests in addition to other social and cultural services particularly to indigenous forest peoples (FAO, 2014). In urban centres close to forests, they are a source of food to over 40 million people (Nasi et al., 2011).

At least $80 \%$ of 5.4 billion hectares of global forests and wooded areas are state owned and a majority of these are under concessionary governance (Agrawal et al. 2008). Since the colonial era, this model of state-centred forest management has been the most common in South East Asia, parts of the Amazon and especially in West and Central Africa (Karsenty et al., 2008; Hardin and Bahuchet 2011). It has been argued that one of the consequences of state controlled forestry or 'forest government' (Arts, 2014) has been the overexploitation of forest resources often in conflict with local forest dependent communities and state conservation objectives (Bose et al., 2012). Forest government is characterized by concessionary systems with erratic or poor effective forest controls in place; corruption in the value and market chain; lack of resources for forest control given the vast areas of forests. The failure of forest government to achieve sustainable forest management has led to calls for multi-stakeholder forest governance processes beyond government (Cashore et al. 2012).

The argument for multi-stakeholder deliberative processes is that public governance by itself is not sufficient to address collective action problems - there is need for governance systems that include non-state actors (Ostrom, 2003; Gutierrez and Morgan, 2017). These new arrangements include innovative non-state governance systems like public private partnerships, markets, private certification schemes, civil society forest monitoring amongst others (Arts, 2014; Trubek and Trubek , 2007; Young 2016).

With the emergence of these innovative governance systems, there have been calls for a deeper understanding and conceptualisation of the formal and informal factors that affect 'real' forest governance (Cashore, 2002; Agrawal et al., 2008; Humphreys 2012). While the role played by private sector in improving sustainable forest management through certification schemes has been widely researched (Cashore, 2002; Auld et al. 2008; Nasi et al. 2012), there is much less rigorous conceptual works of the role of civil society organisations (CSOs) in addressing the core issues of forest governance in the tropics. This lack of knowledge is particularly relevant for some critical issues like illegal logging and related trade in the Congo Basin. This paper focuses on external independent forest monitoring (IFM) initiatives by civil society organisations as a new governance arrangement in the tropics, with one of the Congo Basin countries - Cameroon as case study. According to Brack and Leger (2013, p.11), IFM is suitable in a context such as Cameroon characterised poor governance, weak or ambiguous law enforcement mechanisms undermined by widespread illegality, corruption, cronyism, rent-seeking. In the case of tropical wood supply in Europe for example, the role of IFM was recognised in the European Union's Forest Law Enforcement, Governance and Trade (FLEGT) action plan as a key component of timber legality and assurance systems (Brack and Leger, 2013). 
Past research on the role of IFM in the Congo Basin has largely focused on the role of donor funded international environmental and activist NGOs such as Global Witness, Resource Extraction Monitoring (REM) and AGRECO (Fomete and Cerutti, 2008) while the role of national NGOs has been largely overlooked. In Cameroon, official mandated IFM projects ended in 2013 and since then Civil Society Organisations (CSOs) have struggled to monitor the sector, due to the limited number of actors and largely due to lack of human, material and financial resources. There remains a significant lack of appreciation and acceptance of IFM by local Non Governmental Organisations (NGOs) amongst decision makers in the Congo Basin. In the same lens, there is limited uptake of IFM findings by forest authorities and the very role of civil society in monitoring is contested (Brack and Leger, 2013). As an example, empirical evidences from IFM are not readily taken into account by the private sector, law makers, anticorruption committees, and the justice system. Many donors and practitioners are concerned that national NGO IFM initiatives are producing disappointing results (Young 2016). To some authors, national civil society has not been particularly effective in assuming their role (U4 Brief, 2010). According to Young (2016), much remains to be done in mapping progress, identifying what works and what doesn't work and why, and in providing better understanding of how the different networks operate in their environments to address forest illegality problems. This paper seeks to address some of these issues through participatory observation, documentary content and case study analysis of the standardised system for external Independent Forest Monitoring (SNOIE) in Cameroon.

The following sections review the emergence of independent forest monitoring leading to the theoretical framework and hypotheses of the study. The methodology used is presented followed by the results and discussion sections. The paper ends with implications of the research.

\section{What is Independent forest monitoring by national NGOs?}

IFM entails a third party assessment of the conformity of forest management and forestry activities with the legislative and regulatory standards in force in the forestry sector of the country (Tegtmeyer et al. 2010). The history of IFM dates back to the fundamental changes in the early 1990's towards participatory forestry, with an emphasis on participatory forest resource assessment, and participatory inventory (see for example, Carter 1996). This, very broadly, encompassed a shift from seeing 'forest management', including planning, assessment, forestry practice and resource allocation as a purely professional role to be conducted by civil service or para-military forestry services, to one involving a range of stakeholders and interest groups, not least those directly affected by forestry or logging activities. As this approach matured it broadened out into activities that supported forest policy and provided an evidence-base for policy decision making. One of these innovative areas was independent forest monitoring.

According to Global Witness (2005), IFM arose 'more or less spontaneously', in response to local conditions in Asia and the Congo Basin (Cameroon). Global Witness designed IFM to complement and support official forest law enforcement with the objectivity and public credibility of an independent third party, improving transparency and contributing to the development of a sound legislative and regulatory framework for responsible forest management. Global witness, which was one of the pioneer organisations to promote independent forest monitoring in the tropics, defined IFM as the use of an independent third party that, by agreement with state authorities, provides an assessment of legal compliance, and observation of and guidance on official forest law enforcement systems (Global Witness, 2005). IFM generally comprises of a field-based mission to gain evidence regarding a potential infringement of forest laws. This evidence is compiled in a report, which may be independently reviewed and verified, before being presented to a local governmental authority, usually those of the forest administration (Young 2007). The role of IFM has since evolved to include the implementation of these functions by self mandated national NGOs without the need for agreement with national governments. This is the case in Cameroon where contrary to other countries national NGOs opted to negotiate 
agreements with national governments. However, Cameroon NGOs did not argue for independent monitoring to be recognised in international forest policy instruments, because they believed it could risk a loss of independence by the NGOs conducting the monitoring (NGOs in Ghana and Liberia took the same approach) (Brack and Leger, 2013). As an example, this was the case with EU negotiated voluntary partnership agreement with the government of Cameroon. According to ClientEarth (2017), the notion of 'independence' in IFM relates to impartiality and non engagement of monitors in the subject of their investigations. This allows IFM organisations to interact not only with governments and private sector actors who are directly involved with forest management activities, but with any other national and international actors with the ability to influence forest governance processes.

In the case of the Congo basin region, two main approaches of IFM co-exist; mandated and non-mandated IFM. Under mandated IFM, a national CSO negotiates a contract with the government to implement forest monitoring in support of the official government control function carried out by national forest control brigades. With regards to non-mandated IFM, civil society operates without an agreement or mandate from the government and therefore has greater autonomy in setting monitoring goals (Young, 2016). This paper focused on non mandated IFM which is the only approach operational in Cameroon.

\section{Theoretical framework: governance network analysis}

This paper builds on a governance network analytical framework proposed by Klijn and Koppenjan (2012) with a background in policy studies, public administration and network management research. The governance network approach posits that network outcomes result from the actions of interdependent actors. In short, the notion of governance within the framework of this research refers to "self-organising, inter-organisational networks" (Rhodes, 1996). Three main types of governance networks are identified: policy networks, service delivery and policy implementation networks as well as governing networks (Klijn, 2008). The focus of this study is on governing networks, which seek to address societal problems, managing horizontal governance relationships and connecting governance networks with traditional institutions and deliberative processes. With roots in public administration research, the focus is how to manage networks and integrate them with traditional institutions. The key components of the governance network analytical framework are illustrated below (box 1).

Box 1: Key components of the governance network analytical framework

Actors, interdependencies and frames: according to Klijn and Koppenjan (2012), policy and service delivery is achieved through a network of interdependent actors. The effectiveness of these processes is shaped by how issues are framed, individual values, interests, attitudes as well as the missions and mandates of the organisations they represent (Emerson et al, 2012). Interaction and complexity: According to Gutierrez and Morgan (2017), interactions range from relationships of complementarity, substitution, rivalry and even monopoly. As a consequence of the interdependencies and frames of different actors involved, their perceptions and strategies adopted in the definition and implementation of network activities, different interactions between actors create complexities. According to Klijn and Koppenjan (2014) complexities may lead to stagnation, blockages and success of network actions.

Institutional features: These can be understood as patterns of social relations (interactions, power relations etc.) and patterns of rules" (Klijn and Koppenjan, 2012, pp 5). According to the institutional view, social interactions may result in rule definition and enforcement which regulates the way in which different actors interact thereby enforcing the legitimacy of collective action (Scott, 1995).

Network management: These activities are aimed at facilitating interactions, exploring (new) content and organizing interactions between actors (Klijn and Koppenjan, 2012). Effective network management builds trust between network actors and those they seek to influence. Klijn and Koppenjan (2014) further indicate that successful network management increases interaction and cooperation, reduces complexity, improves the 
achievement of government network outcomes.

\subsection{Effectiveness of governance networks and research hypotheses}

According to Klijn and Koppenjan (2012), effective policy and service delivery in governance networks is achieved through joint action of interdependent actors. In a study of UK and US fishery governance networks, Gutierrez and Morgan (2017) find that the need for collaboration and coordination creates interdependences between actors in goal setting, strategy development and implementation. Recent research by Emerson et al (2012) posit that the effectiveness of these processes is shaped by how issues are framed, individual values, interests, attitudes as well as the missions and mandates of the organisations they represent. Additionally, it is the shared objective to be achieved that facilitates the building of trust and complementarities amongst interdependent actors it is argued (Kossmann et al., 2016). However, Gutierrez and Morgan (2017) also found that the mismatch of structures, objectives and resources, lack of funding, resources and capability, lack of information about each other's processes and absence of reciprocal awareness of each other's actions were key constraints to network effectiveness. Lindahl et al (2017) in a comparative study of governance network models also found that effectiveness was influenced by institutional issues, power relations and path relationships.

A key characteristic of governance networks is the interaction that exists between interdependent actors. According to Trubek, and Trubek (2007) the emergence of new governance forms in sectors regulated by conventional legal processes, allows for a wide range of configurations of interactions to become possible. As a consequence of the interdependencies and frames, perceptions and strategies adopted in the definition and implementation of network activities, different interactions between actors create conditions which may lead to stagnation, blockages and success of network actions (Klijn and Koppenjan, 2014).According to Gutierrez and Morgan (2017), these can range from relationships of complementarity, substitution, rivalry.

Public governance and non-state market-driven governance systems complement each other because of formal or informal coordination. Complementarity occurs when governance mechanisms co-exist in the "same policy domain" and contribute to a "common objective" but have not merged into one governance system (Trubek and Trubek, 2007)." Complementarities emerge due to the need to share resources and a genuine partnership to tackle mutually agreed problems (Clark, 1993). According to Brinkerhoff (1999) complementary interaction generates synergistic effects that can lead to transformative effects in policy and service delivery.

Adversarial relationships or rivalry on the other hand develops when public and non state governance systems compete for authority, or when it is perceived that the new governance regimes perform the same tasks as the legal regulation or even better (Gutierrez and Morgan, 2017). This can also arise when there is a perceived need for end users to choose between systems, where there are questions around the legitimacy and credibility of government led processes. The very first demonstration of this is found in the case of the relationship between Global Witness (GW) as independent forest monitor and Cambodian government in the late 1990s (Humphreys, 2009). GW received World Bank funding to monitor compliance of private sector and government with national legislation. In one of its landmark reports in 1999, GW alleged that government officials were involved in illegal logging and this led to a backlash from government, which accused the NGO of fueling social unrest. Following years of adversarial relationships, this contract was terminated in 2004. Similar responses have been reported in Cameroon with the independent auditors of the Voluntary partnership agreements (VPA) between the government and the European Union on forest law enforcement, governance and trade (FLEGT) which led to the termination of the contract in 2013. In order to build trust, strengthen coordination and address rivalrous situations, Klijn and Koppenja (2012) recommend networking and effective network management by those in charge of steering network activities. 
Substitution effects occur when public and non state actor governance networks co-exist and generate products and or services that actors consider similar enough that they can be substituted (Guitierrez and Morgan, 2017). According to the authors, this can lead to waste, increased costs and duplication of efforts between different governance systems. The benefits of substitution effects emerge for instance where products or services from one system are discontinued for one reason or another. In this paper, we argue that substitution provides resilience and sustainability of access to the products/services by potential users and therefore, has a positive effect on achieving network goals.

Hypothesis 1: Complementary and substitution interactions between independent forest monitoring network actors are positively related to achievement of improved forest governance outcomes

Hypothesis 2: Adversarial/rivalrous interactions between independent forest monitoring network actors network actors and other national forest agencies is negatively related to achievement of improved forest governance outcomes

\section{Methodology}

\subsection{Data collection}

This research adopted a mixed qualitative methods approach consisting of participatory observation, documentary content and case study analysis (Klijn \& Koppenjan, 2012). According to White and Marsh (2006) content analysis is a research technique for making replicable and valid inferences from text (or other matter) to the context of their use. The authors explored documentary evidence, grey literature and case studies addressing multi-stakeholder processes in the Congo Basin in line with IFM. This involved online information searches on project websites, conference reports, annual organisational reports and keynote statements and presentations of experts in key conferences and seminars. IFM related project reports managed by the lead author in the Congo Basin were reviewed. The first project (DCI-ENV /2013/323-906) was a two-year EU development project implemented in Cameroon and Central African Republic (CAR) between 2014 and 2016. The project focused on the promotion of forest peoples' rights in national forest governance processes. All reports exploited care accessible via the project website. The second project (ENV/2016/380-500) is a four-year EU project (2017 to 2020) with specific objective of strengthening civil society led IFM and advocacy. Following White and Marsh (2006), we moved from the constructs of the governance network analytical framework and the researcher's expertise in the area to scan the texts (reports, articles) collected. This allowed us to identify broad subject headings in line with the framework. A closer analysis was then carried out on each report to identify and make inferences on the different issues addressed in line with the effectiveness of the IFM network in Cameroon.

\subsection{SNOIE case study}

In 2015 a group of NGOs in Cameroon came together and began to put in place a system for civil society led IFM within the context of the FLEGT VPA process. This network allows national NGOs to collaborate with international advocacy agencies and the state forest bureaucracies mainly the Ministry of Wildlife and Forests (MINFOF) in Cameroon. The aim of this initiative was to address forest governance failures. The national NGO Forêts et Développement Rural (FODER) has played a steering role and coordinated the interactions within the IFM network. This network is made up of 12 other NGOs as well as the subsidy of an international partner named Transparency International Cameroon leading advocacy actions. Part of the network includes an innovative multistakeholder governance structure functioning as a 'reading committee' which examines and validates IFM reports before publication. A member NGO is designated by the general assembly to manage the network and links between the IFM coordination unit 
and national government agencies especially the national forest control brigade of MINFOF, ministries of agriculture, social affairs and justice.

SNOIE's development was driven by a bottom-up observation that 'classical IFM' hadn't delivered the required change and improvements in forest law enforcement and governance: responsiveness to IFM reports was very low by both the government and private sector, and the approach to civil society led monitoring has been very weak, using diverse methodologies and tools, and missing coordination of actions and approaches related to Independent Monitoring. Stakeholders, primarily NGOs involved in independent monitoring, wanted a standardised methodological approach to address these issues. The IFM network established a standardised system of independent observation (SNOIE) as a set of operating methods for monitoring of natural resources based on an international standard (ISO 9001: 2015) which includes observation, verification, communication, and lobbying. The SNOIE seeks a clear division of the roles of the monitoring or partner organisations involved in the system.

\section{Results}

\subsection{Actors, roles, interests and characteristics of the IFM network in Cameroon}

In developing the SNOIE system in Cameroon, FODER carried out a wide stakeholder analysis which allowed them to engage different stakeholder groups in goal and strategy setting including government agencies (Figure 1).

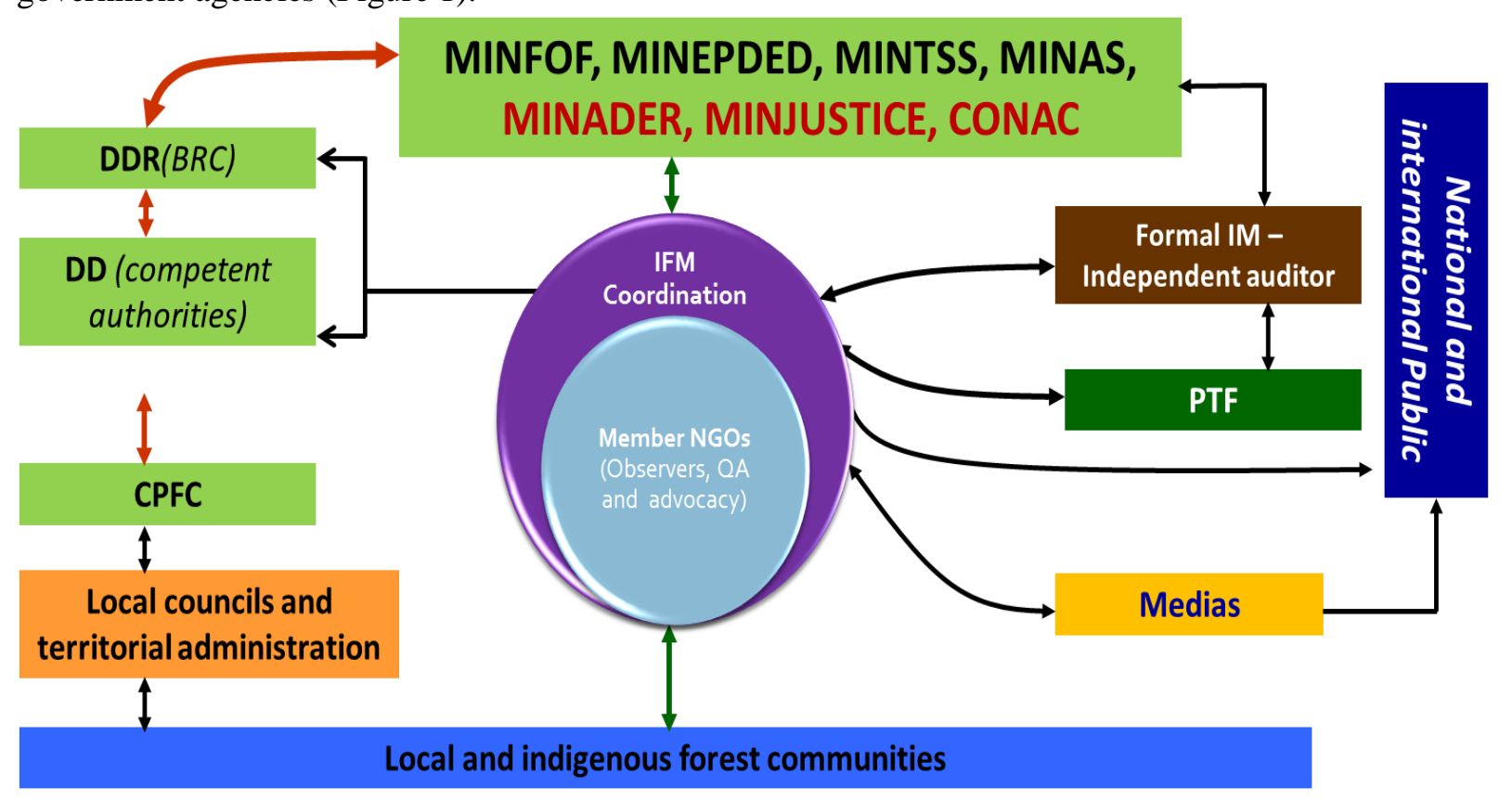

Figure legend: MINFOF = Ministry of Forests and Wildlife; MINEPDED: Ministry of Environment, Nature Protection and Sustainable Development; MINTSS: Ministry of Labour and Social Security; MINAS: Ministry of Social Affairs; MINADER: Ministry of Agriculture and Rural Development; CONAC: national Anti-Corruption Commission; DD = Divisional Delegation; DDR $=$ Regional Delegation; $\mathrm{CPFC}=$ Chief of Forest and Wildlife Control Post; PTF $:=$ Technical and Financial Partners

Figure 1: An application of SNOIE network model in independent forest monitoring system in Cameroon

Figure 1 identifies the different actors involved in the IFM governance network in Cameroon. This includes internal actors comprised of 12 national NGOs that make up the network and the network 
management group represented by the IFM Coordination. To ensure that there is effective response and impact from IFM reports, the network actively engages with external actors such as national and decentralised state bureaucracies, local and indigenous forest communities, media, VPA implementation units, national and international interest groups. This is also because of the shift from "classic IFM" that has tended to focus on the technical aspects of forestry to include social concerns related to the respect of social obligations, safeguards, as well as community and workers' rights, which are of interest to wider stakeholder groups. Though SNOIE operates without a formal mandate from government, national NGOs fully acknowledge the sovereign forest control and enforcement role of the state and create opportunities for complementarity and collaborative action while ensuring objectivity and impartiality in the implementation of field investigations and reporting. Table 1 identifies the actors, roles and interest of non state actors in the IFM network while table 2 focuses on the formal roles and interests of state bureaucracies in IFM.

Table 1: Mapping of self defined roles and interests in IFM by civil society actors in Cameroon

\begin{tabular}{|c|c|c|}
\hline $\begin{array}{l}\text { Category of } \\
\text { actor }\end{array}$ & Self defined role & Formal interests and actions \\
\hline National NGOs & $\begin{array}{l}\text { Watchdog, citizen control } \\
\text { Advocacy for community rights } \\
\text { Representation of forest } \\
\text { dependent communities } \\
\text { Technical assistance to } \\
\text { communities }\end{array}$ & $\begin{array}{l}\text { Monitoring forest law enforcement and } \\
\text { compliance of actors with national legislation, } \\
\text { environment and social norms }\end{array}$ \\
\hline $\begin{array}{l}\text { Transparency } \\
\text { international }\end{array}$ & $\begin{array}{l}\text { Advocacy for 'good } \\
\text { governance' }\end{array}$ & $\begin{array}{l}\text { promotion of law enforcement, assessment of } \\
\text { corruption index in forest sector }\end{array}$ \\
\hline $\begin{array}{l}\text { Communities } \\
\text { (forest) }\end{array}$ & $\begin{array}{l}\text { Informants } \\
\text { Rights defenders }\end{array}$ & $\begin{array}{l}\text { Claiming a better benefit sharing system from } \\
\text { forests } \\
\text {, improving livelihoods and forest } \\
\text { Preservation }\end{array}$ \\
\hline Media & $\begin{array}{l}\text { Communication of IFM findings } \\
\text { and studies }\end{array}$ & $\begin{array}{l}\text { Promoting increased transparency in forest } \\
\text { sector }\end{array}$ \\
\hline $\begin{array}{l}\text { IFM } \\
\text { coordination }\end{array}$ & $\begin{array}{l}\text { Network management } \\
\text { Facilitate network meetings } \\
\text { Coordination with external } \\
\text { actors }\end{array}$ & $\begin{array}{l}\text { Rule setting, internal audits and commissioning } \\
\text { of external audits } \\
\text { Effectiveness and efficiency of IFM function } \\
\text { Visibility of IFM functions and network }\end{array}$ \\
\hline $\begin{array}{l}\text { Technical and } \\
\text { financial } \\
\text { partners }\end{array}$ & $\begin{array}{l}\text { Technical and financial } \\
\text { assistance }\end{array}$ & $\begin{array}{l}\text { Improving forest governance by strengthening } \\
\text { accountability and multi-stakeholders } \\
\text { participation, production and dissemination of } \\
\text { reliable information, providing funding and } \\
\text { training opportunities, etc. }\end{array}$ \\
\hline
\end{tabular}

Table 2: Mapping of roles and formal interests of national and decentralised state authorities regarding IFM in Cameroon 


\begin{tabular}{|c|c|c|}
\hline Category of actor & Formal role & Formal interests in IFM goals \\
\hline MINFOF & $\begin{array}{l}\text { Sovereign role - legal /forest owner } \\
\text { Forest control and enforcement } \\
\text { Coordination and facilitation of } \\
\text { national level governance processes } \\
\text { Traceability systems } \\
\text { Attribution of rights } \\
\text { Tax distribution and investments }\end{array}$ & $\begin{array}{l}\text { Increasing credibility of forest control } \\
\text { function } \\
\text { Increasing transparency in the forest } \\
\text { sector } \\
\text { Increasing incomes and improving } \\
\text { benefit sharing from forests } \\
\text { Reducing forest illegality and related } \\
\text { trade }\end{array}$ \\
\hline MINADER & $\begin{array}{l}\text { Formal administration in charge of } \\
\text { agricultural development including } \\
\text { granting of forest areas for agri- } \\
\text { business }\end{array}$ & $\begin{array}{l}\text { Monitoring of allocated permits for } \\
\text { agricultural development }\end{array}$ \\
\hline MINJUSTICE & $\begin{array}{l}\text { Application of national legal and } \\
\text { penal code }\end{array}$ & fostering justice in forest sector \\
\hline MINAS & $\begin{array}{l}\text { Enforcement of social obligations of } \\
\text { companies and community rights }\end{array}$ & Fostering social equity in forest sector \\
\hline MINEPDED & $\begin{array}{l}\text { Environmental protection and } \\
\text { conservation }\end{array}$ & $\begin{array}{l}\text { Promoting social and ecological } \\
\text { sustainability in forest sector }\end{array}$ \\
\hline MINTSS & $\begin{array}{l}\text { Workers' rights and working } \\
\text { conditions in forest companies }\end{array}$ & $\begin{array}{l}\text { Access to credible information and } \\
\text { promoting of labour law enforcement in } \\
\text { forest sector }\end{array}$ \\
\hline $\begin{array}{l}\text { Local councils and } \\
\text { territorial } \\
\text { administrations }\end{array}$ & $\begin{array}{l}\text { Decentralised forest control } \\
\text { Management of special forest } \\
\text { development funds } \\
\text { Local oversight of forest rights } \\
\text { holders }\end{array}$ & $\begin{array}{l}\text { Overall coordination of forest operations } \\
\text { and promotion of related } \\
\text { local development }\end{array}$ \\
\hline $\begin{array}{l}\text { Independent } \\
\text { auditor of the VPA }\end{array}$ & Audit of the VPA system & $\begin{array}{l}\text { Source of information and third party } \\
\text { verification } \\
\text { Encouraging production of reliable, } \\
\text { credible and relevant information }\end{array}$ \\
\hline CONAC & Fight against corruption & $\begin{array}{l}\text { Assessing corruption and facilitating } \\
\text { credible information in forest sector }\end{array}$ \\
\hline
\end{tabular}

In line with the governance network analytical framework, table 3 provides a summary of key characteristics of the IFM network concerning goal setting, strategies and network management activities 
as well as examples of how these play out in practice. The table portrays the IFM model as a multistakeholder driven and experimentalist network. For instance through adoption of ISO 9001 standards for field monitoring, the establishment of a reading committee and strong experimentation with modern technologies, social media and satellite imagery to strengthen credibility and reliability of independent forest monitoring reports and publications.

Table 1: Characterisation of strategies, rule setting and management features within IFM network

\begin{tabular}{|c|c|c|}
\hline Item & Feature & Examples \\
\hline Strategy & $\begin{array}{ll}- & \text { Community alert system } \\
- & \text { Use of satellite and mobile technologies } \\
\text { - } & \text { Independent and joint field monitoring } \\
\text { - } & \text { missions with state administrations } \\
- & \text { Publication of reports } \\
\text { - } & \text { Advocacy } \\
- & \text { External independent audits } \\
- & \text { Capacity building } \\
- & \text { Media engagement } \\
\end{array}$ & $\begin{array}{ll}\text { - } & \text { Communities use mobile phones to } \\
\text { send alerts to IFM NGOs (forest link) } \\
\text { - } \\
\text { Reading committees comprise of } \\
\text { NGOs, national forest control brigade, } \\
\text { judiciary and NGOS } \\
\text { - External audit of the quality } \\
\text { management system }\end{array}$ \\
\hline $\begin{array}{l}\text { Network } \\
\text { manage } \\
\text { ment }\end{array}$ & $\begin{array}{ll}\text { - } & \text { leadership of the IFM coordination by a } \\
\text { national NGO } \\
\text { - } \\
\text { - } \quad \text { Monthly coordination meetings } \\
\text { facilitate communication } \\
\text { - } \quad \begin{array}{l}\text { Coordination meetings with national } \\
\text { forest administration }\end{array}\end{array}$ & $\begin{array}{l}\text { - The IFM coordination holds quarterly } \\
\text { meetings to review and plan activities } \\
\text { but also share information and } \\
\text { coordination } \\
\text { - A WhatsApp group enhances real } \\
\text { time sharing of information amongst } \\
\text { network actors }\end{array}$ \\
\hline $\begin{array}{l}\text { Rule } \\
\text { setting }\end{array}$ & $\begin{array}{ll} & \text { General assembly meetings of members } \\
\text { agree on roles and responsibilities, action } \\
\text { plans and budgets } \\
\text { - } \quad \text { Labeling and certification of specific or } \\
\text { overall process is issued } \\
\text { - } \quad \text { Internal quality management reviews }\end{array}$ & $\begin{array}{l}\text { - An annual general assembly of the } \\
\text { IFM coordination is organised } \\
\text { - } \quad \text { ISO } 9001 \text { provide the guidelines for } \\
\text { quality assurance and evaluation of } \\
\text { performance } \\
\text { - Bi-monthly quality reviews ensure } \\
\text { standards are applied and staff } \\
\text { capacities are regularly updated } \\
\text { - Use of FLEGT WATCH radar based } \\
\text { alert system and real time monitoring } \\
\text { mobile applications }\end{array}$ \\
\hline
\end{tabular}


In addition to the features identified in table 2, funding and organisational capacities were also identified as key factors affecting IFM effectiveness. With regards to funding, results show that the IFM network is completely dependent on external funding from initiation. This situation represents a key weakness of the network activities suggesting that financial sustainability is in danger. Even where NGOs succeed to raise funding for IFM, this tends to be short term and intermittent suggesting that these actions are very likely to be interrupted once funding runs out.

As with the funding of IFM field missions, a lot of donor funding has gone into building organisational and operational capacities of IFM NGOs in order to improve their performance and longterm sustainability contributions. Results of capacity needs assessments of IFM organisations in Cameroon. This was the case by the Centre for International Development and Training (CIDT) in 2014 which highlighted weak organisational capacities in areas of gender mainstreaming, leadership and strategic skills, financial management and external relations. Weak organisational and institutional abilities are likely to affect effectiveness of IFM activities.

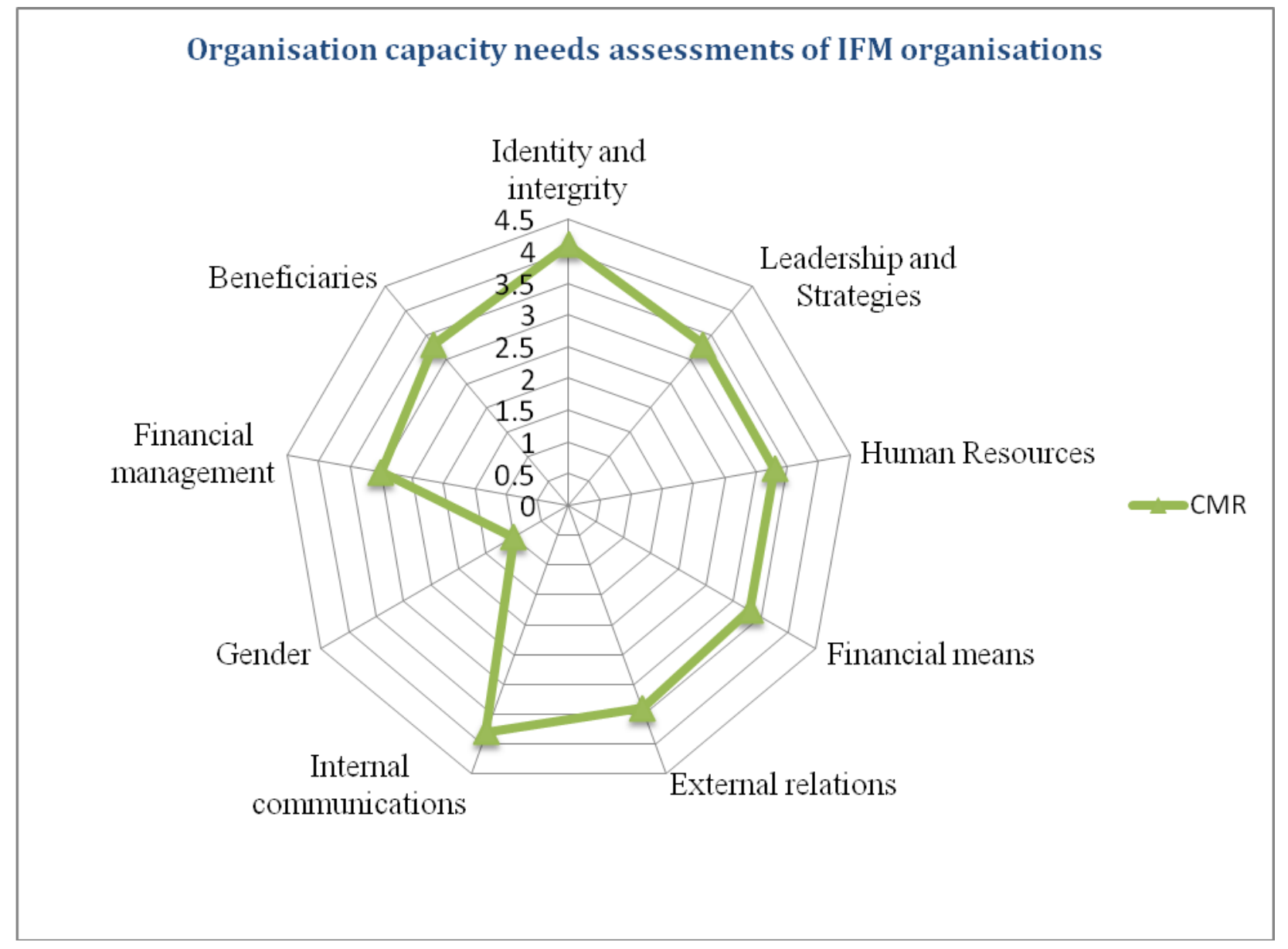

Figure 2: Organisational capacity needs assessment of IFM organisations in Cameroon Source: CIDT (2014)

A key characteristic of governance networks is interaction between interdependent actors. As highlighted before, these interactions and strategies adopted by different actors create complexities which can lead to blockages, stagnation and in many cases deliver positive impact and desired outcomes. 


\subsection{Interactions and complexities in the governance of independent forest monitoring}

\subsubsection{Complementarity}

Complementarity is demonstrated in this case study as IFM is seen to complement the official government forest control function all seeking to improve transparency, accountability and forest law enforcement. A key component of the VPA is the establishment of timber traceability and legality assurance systems. The role of independent monitors is widely acknowledged as having an important watch dog role to ensure that private sector as well as government actions operate in respect of the law through out the timber value chain. The participation of civil society in these processes is seen to strengthen the credibility of government led systems and therefore by opening up space for IFM, national state bureaucracies demonstrate their openness to stakeholder engagement and citizen participation. Even though the SNOIE network does not have a formal mandate with the governmental authorities, NGO actors have put in place systems to engage with forest administration (MINFOF). For instance, FODER will not publish reports without first of all submitting them for examination by a multistakeholder reading committee and MINFOF. As a result of the separation of roles and quality of IFM outputs, MINFOF through its national forest control brigade is increasingly taking part in joint field missions initiated by FODER and vice versa. The Ministry regularly invites IFM organisations to join field missions in order to verify claims made in NGO reports. This is interesting because it demonstrates a convergence in approaches between mandated and non mandated IFM towards government. It is a recognition that at the end of the day only the government has the power to sanction, enforce or bring defaulters to justice. For this to happen, NGOs must demonstrate credibility, professionalism, quality in their activities and respect for the national legislation in force. The response by private sector and forest dependent communities to the complementary actions of NGOs and government agencies is mixed. On the one hand, communities value their role as guardians of the forest through improved response and verification of transmitted alerts through geo-referenced reports of forest illegalities using mobile phones and smart technologies (Rainforest UK, 2019). On the other hand, private companies engaged in illicit activities are less receptive because of the increased presence of independent third parties in their areas of intervention. The evidence shows that SNOIE reports have led to increased government controls, fines and sanctions against companies for illegal behaviour (FODER, 2017). For instance, the forestry company Oye et Compagnie was fined the sum of 7.5 million FCFA (12,000 euros) by the Ministry of Forests and Wildlife (MINFOF) following a denunciation report produced by the organisation PAPEL (Support Programme for Livestock Production and Conservation of Biodiversity in Protected Areas) which is part of the SNOIE network in 2018 (Kouetchua, 2018).

The advocacy function implemented by Transparency international Cameroon Chapter in this case further highlights the importance of complementarity as well as the role of power relationships in achieving network goals. NGOs led governance networks find justification to engage with government agencies including traditional law enforcement agencies and law makers in order to develop mutually beneficial relationships. However, being very close to state bureaucracies and related authorities also comes with a lot of risks especially in authoritarian and corrupt regimes characteristic of the Congo Basin region (Ongolo and Karsenty, 2015) as NGOs become exposed to the loss of their autonomy, security and corruption attempts. These can very easily lead to adversarial relationships and rivalry in the interactions between state bureaucracies and non-state governance networks.

\subsubsection{Rivalry}

As mentioned before, many in the target countries continue to see international forest monitoring organisations as donor led and driven by international activist NGOs to criticise private sector and 
government actions especially in postcolonial countries. In Cameroon for instance, SNOIE reports of officials involved in illegal forest practices led governmental authorities to dismiss and sanction and transfer divisional delegates in some regions in 2018. Private sector companies are completely opposed to NGO led IFM interestingly they argue because they don't have any mandate from national government despite the role of IFM clearly articulated in national forest legislation or provisions of the VPA. State bureaucracies criticise them for violation of national sovereignty, their alleged negativity and conspiracy with international activist organisations to tarnish government's image and the national timber market. For instance, Greenpeace published a scathing report in 2015 about illegal behaviour of a Cameroonian company "Compagnie De Commerce et de Transport (CCT)" (Greenpeace Netherlands, 2015). This report was met by a brutal response from a former Minister of Forestry in Cameroon -Philip Ngwese Ngole- who disparaged the report as being built on false truths. On 8 March 2016 the Dutch Food and Consumer Product Safety Authority (NVWA) reported it had filed a report with the public prosecutor against a Dutch company alleged to have done business with the Cameroon Company in bridge of the EUTR. The Dutch company was issued a conditional penalty to be paid if they continued to do business without an effective due diligence system. Many decision-makers in Cameroonian state bureaucracies accused national IFM organisations to have been at the origin of the information contained in the Greenpeace report. This situation creates an environment of mistrust amongst public and non government actor networks. Ongolo and Karsenty (2015) refer to the "blame avoidance" theory to argue that state bureaucracies in areas of limited statehood or fragile states use these tactics to avoid responsibility in forest governance failures as they strive to manipulate the public opinion away from the issues and to protect private rents and benefits to powerful elites, dominant policy-makers and their private allies.

Another area of rivalry is in access to financial, human and material resources especially from international donors. Many governments in the tropical regions justify weak forest law enforcement to the lack of adequate financial, material and human resources. In an era characterised by national debt and increasingly stringent conditions for accessing donor funding, government departments struggle to raise resources for their formal and informal agenda (Karsenty and Ongolo, 2012; Ongolo and Karsenty 2015). On the other hand, recipient state bureaucracies accuse donors of funding NGO projects and for fuelling the activities of non elected NGO representatives. In these cases competition, disputes and mistrust develops between networks because many public administration officials protest about the fact that NGO staff are better paid and have better working conditions. Consequently, this means that when joint missions are organised, government staff may intentionally refuse to document infractions or to record/propose sufficient fines for observed illegalities. In other instances, State bureaucracies' officials ask for payments from NGOs when they are requested by their departments to accompany NGO staff to the field. Rivalries are also identified within government departments -the case of regular disputes between the ministry of forestry and the ministry of environment in Cameroon- as well as amongst different IFM organisations.

With regards to rivalries within government departments, the case also highlights the lack of convergent interest and collaboration between some specific key state bureaucracies of forest sector such as the ministry of forestry, the ministry of environment, the ministry of economy, police forces and judiciary. In Cameroon as in many countries in the Congo Basin, the most influent ministries in forest policy domain prefer to engage in transactions with private sector companies that have been identified in IFM reports. Through the process of transaction, fines and sanctions can be watered down and informal payments made for the benefit of government officials as opposed to the public treasury. Recent evidence from Cameroon suggests that state officials collect over 6 million euros per year in informal taxes and hence there is no intention to promote transparency, equity or accountability (Cerutti et al. 2013; Ongolo and Karsenty, 2015). The strangle hold of the ministries of forests in this direction means that there is no interest to include traditional law enforcement agencies. This situation perpetuates a vicious cycle of corruption and creates unintended effects from the view point of IM organisations. In fact IM reports become a source of relevant information for government officials who use the information to enter into transactional arrangements with companies or individuals alleged to be involved in illegality. From 
private sector perspective particularly those involved in illegal activities this maybe facilitating the legalisation of illegal timber. These behaviours only add to the problem of unfair competition between illegal companies and those which seek to respect the law. Further research should explore the extent to which more law abiding or "citizen companies" may be willing to report and denounce the behaviour of their illegal competitors. Such evidence could facilitate collaboration between NGOs, national government and private sector in real public private partnerships in the fight against illegal logging.

Within NGO actor groups, rivalry is observed in the Cameroon where only a limited number of NGOs regularly obtain donor funding. Within the SNOIE network with 12 NGOs in Cameroon, less than three have access to long term funding for IFM. Under these circumstances, the more successful NGOs grow in status and the unsuccessful ones develop dependency relationships becoming agents or get demotivated and opt of networks. Furthermore, even when NGOs identify other complementary resources which they bring to the networks (such as leadership, technical expertise and closeness to forests and forest dependent communities), questions about funding remain a significant threat to network performance. It is important to note that rivalries do not always result in negative outcomes for networks as demonstrated here but can also create further opportunities for joint action and innovation.

\subsubsection{Substitution}

Substitution manifests itself when non state and state governance systems co-exist and produce outputs and services that actors consider similar enough that they can be substituted (Guttierez and Morgan, 2017). We identify substitution in the area of information portals for publication of forestry information. In Cameroon for instance the government has as part of its commitments under the VPA, created an information portal for the forest sector. This is intended to be a one stop shop where stakeholders can readily access up to date information about the forest sector including information about forest illegalities and actions undertaken by the governmental authorities to enforce the law. Parallel to government information portals, IM organisations publish their reports on the internet and on social media. A good example is the open timber portal developed by World resources Institute and national IFM actors in Cameroon which is a georeferenced repository of IFM reports. National and international actors seeking information about the forest sector in the Congo Basin have the opportunity to access both government and NGO information portals. The case of information portals is interesting because government websites are often criticised for not being operational most of the time, that information is not updated on a regular basis or that many mandatory documents are not uploaded nor can be downloaded by users. Some users regularly question the accuracy of reports published by the ministry of forestry in terms of the issue of trust in the source. NGO operated websites may be more functional and up to date but with limited access to official government documents, end users have to decide which sources of information to use or to trust.

There is no current source for forest control reports controls carried out by forest administrations or police forces in the Congo Basin. For this reason, the only sources of information can be obtained from individual forest company websites particularly those that are labelled by forest certification standards where summaries of auditor's reports can be accessed. Civil society reports and information platforms provide alternative sources of information for different actors. The SNOIE network by using ISO 9001 quality management standards seeks to play a significant role through improving the credibility and reliability of its outputs (Interphase, 2018). There is already evidence that even the state bureaucracies increasingly use this information and considers this system favourably given the increased level of response to IFM reports from the system. 


\section{Discussion}

For the past decades, international development actors have been trying to improve the way forest policies are designed, implemented and evaluated in Africa through the 'good governance' agenda in view of serious failures (Ongolo and Karsenty, 2015). One of the policy instruments promoted by the European Union in this direction has been the introduction of the FLEGT VPAs as a tool to engage timber producing countries in the fight against illegal logging and related trade in tropical regions. This initiative strongly promotes the engagement of other actors beyond government in the various policy processes to ensure responsiveness, legitimacy and effectiveness. It is argued that increased deliberation, cooperation, and learning at local level will enhance integration of the concerns of local circumstances, build on local knowledge and capacities, and result in greater stakeholder ownership and "buy-in" (Gunningham, 2009).

The objective of this paper was to explore the role of IFM networks in improving forest governance in Cameroon by using an innovative governance network approach. By so doing it responded to calls for research to improve understanding of new governance models in the forest sector (Agrawal et al., 2008). The paper used a case study approach to analyse the function of an IFM network, to evaluate the factors which facilitate or constrain its effectiveness. Building on the complementarity, substitution and transformation frameworks proposed by Trubek and Trubek (2007) and further expanded by Guitierrez and Morgan (2017), the paper explored the outcomes of different forms of interaction between actors and outcomes.

\subsection{Initiation and operation of IFM networks}

This research shows that a number of factors contributed to effective initiation and creation of the IFM network in Cameroon to address forest governance challenges. The paper found that FODER, a national NGO, adopted a participatory and inclusive approach, maintained open dialogue in goal setting, strategy development, definition of roles and rules of engagement with different actors. This is demonstrated in the process of experimentation of quality management systems to address IFM challenges and weaknesses. For instance FODER carried out a stakeholder analysis at the beginning which allowed them to identity relevant actors, their interests and map out their power and influence positions. According to Brinkerhoff (1999), these approaches allows for a degree of convergence as starting point given the broad range of interests, power differential as a result of differences in resource levels, operational capacity and political clout.

\subsection{Interdependencies of actors}

In Cameroon the SNOIE network does not have a formal mandate with national government but do have a strong engagement strategy with some state bureaucracies such as forest administration, parliamentarians and media. This supports the recommendations from Fox (2016) that developing closer links with key powerful actors can lead to positive network outcomes. Our research further shows a level of convergence between NGO actions and the importance of engaging with those with an elected mandate to enforce the law. The example here further demonstrates the role of political will and coordination between government departments in support of Somorin et al (2013) who reiterate the role of capacities and competencies, formal and informal institutions as factors which can facilitate or constrain interaction and coordination.

\subsection{Capacities for action}

Managing interdependencies between key actors is essential for effectiveness of policy management and state-civil society collaboration (Brinkerhoff, 1999) yet we found that managing external relations linked to negotiation skills, skills to bind actors and skills to forge new solutions that appeal to various 
actors whose resources were are required to implement solutions were weak (see figure 2). In support of Humphreys (2009), we found that relationships between state bureaucracies and NGOs are fluid and sometimes tense. Coupled with the organisational weaknesses identified, NGO actors need to develop the skill set to foresee and deal with adversarial issues.

\subsection{Complexities in interactions and the role of state bureaucracy}

This paper paints a very complex image of interactions in this process between interdependent actors - government actors, private sector, communities, NGOs in the fight against illegality and related trade in Cameroon. This research finds that relationships between actors are not linear and sometimes are even erratic/opportunistic (Kossmann et al. 2016). The evidence suggests that governance network actions sometimes result in win win situations and positive outcomes where there are complementarities but often take time, transaction costs, power relationships drive issues and sometimes results in communications of the deaf, disappointments where rivalries exist. Our findings were largely in line with extant research in the area of governance networks. For instance, we found that the legitimacy and authority of surveillance by unelected and unaccountable individuals (Green et al. 2007) within the IFM network was often a source of tension as a result of unfavourable reports (Humphreys, 2009). We identified inertia from state bureaucracies to act on reports (Richards et al.2003) which demonstrated weak state bureaucracy commitment to forest law enforcement especially in Cameroon (Ongolo and Karsenty, 2015).

Through this paper, we also identify the role of monopolies and substitution effects in the forest monitoring and law enforcement landscape on the basis of the stated roles and manifestations of civil society and government actions. Monopolies emerge when actors possess sole authority and therefore have a monopoly over certain governance tools (Gutierrez and Morgan, 2017). As already revealed in the analysis, the IFM model recognises the sovereign role of the state in forest law enforcement and the tools at its disposal. Starting with forest governance reform and international conventions, government entities have sole responsibility to negotiate and sign agreements with international organisations with regards to SFM. This includes the voluntary partnership agreements as well as the emerging REDD+ arena. With regards to forest control, only sworn officials can issue fines, sanction and arrest individuals alleged to be involved in illegal activities. While government entities may have monopoly to issue sanctions, civil society organisations also have some options at their disposal. This involves naming and shaming which can affect the image and credibility of those involved. The framing of issues in this case is usually a source of rivalry between different governance systems which can cause stagnation and blockages in the realisation of network goals. The emergence of substitution effects between government and NGO information portals further strengthens the argument for increased participation of non state actors in tackling illegal logging and improving transparency in the forest sector. Through the operation of non state and state information portals, information needs of different stakeholder groups are satisfied in a timely matter in the absence of up to date or credible government reports or forestry information. In a way these portals could be seen as redundant/duplicative and costly if they provide the same functionalities and service but also provide resilience in the sense that one system provides services when the other is down. This resiliency can also be tested if funding for one system were to be curtailed, so having alternatives means that users and citizens can continue to have oversight of the sector.

\subsection{Trust building, synergies and complementarity}

Building trust between network actors emerged as a very significant factor in achieving positive network outcomes. The case of SNOIE shows that trust develops when network goals, strategies and actions are built on bi-directional understanding and participatory dialogue. When complementarities and synergies were emphasised, network actors were more likely to feel valued and to engage positively with relevant processes. The IFM system in Cameroon is built on certification of quality management processes as a way of improving trust in monitoring outcomes and increasing the legitimacy of civil society actions. Trust relationships are also identified through the organisation of joint research and fact finding missions 
between government agencies and NGOs (Koppenjan and Klijn, 2004). The current model of collaboration still shows signs of weakness and mistrust. In multiple cases where independent missions have been organised by the IFM network, government departments and the advocacy partner Transparency International will still organise separate field missions to cross check and verify claims made by NGOs. This suggests that even though the SNOIE system has been externally audited and certified as ISO9001 compliant, national stakeholders still have doubts or are yet to trust the integrity of the system to deliver credible monitoring outputs. It also demonstrates a weakness in the design and operation of the network especially the role of unilateral actions of international 'good governernace'based organisations, like Transparency international, in field missions. For non network actors the role of Transparency international may actually undermine the established systems in place. Duplicative field missions lead to a waste of limited resources and inefficiencies. Koppenjan and Klijn (2012) recommend strengthening coordination between network actors as one of the right conditions to address trust issues within networks.

\section{Conclusion}

The governance network framework proposed by Koppenjan and Klijn (2012) provided a useful lens to assess the functioning of the IFM governance network in Cameroon. Additionally, Trubek and Trubek (2007) and Gutierrez and Morgan (2017)'s framework on the interaction of governance systems provided new insights into how network actors interact amongst themselves but also with external state governance systems they seek to influence. By drawing on these rich theoretical foundations, this research allowed us to have a more comprehensive understanding of the key success of the governance factors for IFM in Cameroon but also the challenges which may undermine its effectiveness.

We also highlighted the lack of financial viability of IFM initiatives which has the potential to undermine the NGO's ability to monitor and hold those in decision making positions accountable. Drawing on experience from the Central African initiative (CAFI) in the Congo Basin, a basket fund model could be a good starting point toward an efficient solution where interested donors contribute funding which is then granted by a fund management unit to IFM organisations. An additional approach could be to explore IFM funding from fines collected by national governments as a result of IFM actions. The Indonesian experience of an IFM fund (Independent forest monitoring fund, 2018) presents an interesting case study to draw on. Future research could explore the possibility of an IFM fund to ensure financial sustainability drawing on limited experiences from the Indonesian VPA. We also found that NGOs lack the capacity and skills to navigate the fluid relationships between different governance systems. Actors need to emphasize complementarities and substitution effects in their attempts to manage rival and adversarial situations in order to maintain pacific coordination especially with government. In this direction, this paper joins Arts (2014) in that the role of the state has not diminished at all in the area of forest control and law enforcement.

Funding: This work was supported by the European Union [ENV/2016/380-500]; and the University of Wolverhampton's Research Investment Fund 3.

\section{Bibliography}

AGRAWAL, A., CASHORE, B., HARDIN, R., SHEPHERD, G., BENSON, C AND MILLER, D. 2013. Background paper 1 - economic contributions of forests. United Nations Forum on Forests, Tenth Session - 8-19th April, 2013. 
AGRAWAL, A., CHHATRE, A. and HARDIN, R. 2008. Changing governance of the world's forests. Science 320(5882): 1460-1462. DOI: 10.1126/science.115536

AQUINO, A and GUAY, B. 2013. Implementing REDD+ in the Democratic Republic of Congo: An analysis of the emerging national REDD+ governance structure. Forest Policy and Economics, 36, 71-79.

ARTS, B. 2014. Assessing forest governance from a "Triple G" perspective: Government, governance, governmentality. Forest Policy and Economics 49(2014) 17-22

AULD, G., GULBRANDSEN, L. H., and McDERMOTT, C. L. (2008). Certification schemes and the impacts on forests and forestry. Annual review of environment and resources, 33, 187-211.

BOSE, P., ARTS, B. and VAN DIJK, H., 2012. "Forest governmentality": a genealogy of subject-making of forest-dependent scheduled tribes in India. Land Use Policy 29 (2012) 664 - 673.

BRACK, D. and LEGER, C. 2013. Exploring credibility gaps in voluntary partnership agreements - a review of independent monitoring initiatives and lessons to learn.

BRINKERHOFF, D.W. 1999. State-civil society networks for policy implementation in developing countries. Policy Studies Review 16(1) 123-147

BROWN, D. 2009. Building national capacity for forest governance reform: the role of institutions. World Forestry Congress, Buenos Aires, October 2009. Session 6.3 Governance and Institutions, pp 1-22

BYRON, N and ARNOLD, M. 1999.. What futures for the people of the tropical forests?. World development, 27(5), 789-805.

CASHORE, B. and STONE, M. 2012. Can legality verification rescue global forest governance?: analyzing the potential of public and private policy intersection to ameliorate forest challenges in southeast Asia. Forest Policy and Economics 18 (2), 13- 22

CARTER, J. 1996. Recent Approaches to Participatory Forest Resource Assessment. Rural Development Forestry Study Guide 2, Overseas Development Institute, London

CERUTTI, P.O., LESCUYER, G., ASSEMBE-MVONDO, S. and TACCONI, L. 2010. The challenges of redistributing forest-related monetary benefits to Local governments: a decade of logging area fees in Cameroon. International Forestry Review 12: 130 -138

CERURRI, P. O., TACCONI, L., LESCUYER, G. and NASI, R. 2013. Cameroon's hidden harvest: commercial chainsaw logging, corruption, and livelihoods. Society \& Natural Resources, 26(5), 539-553.

CLARK, J. 1993. The state of the voluntary sector. Human Resources Department and Operations Policy. The World Bank, Report No HROWP, pp 1-22. 
CLIENTEARTH.2017. Independent forest monitoring - experiences from Congo shared in Ivory Coast; https://www.clientearth.org/independent-forest-monitoring-experiences-from-congo-shared-inivory-coast/ accessed 16.04.2019

DIAZ-BALTEIRO, J., GONZALO-PACHON, C. and ROMERO, C. 2017. Measuring systems sustainability with multi-criteria methods: A critical review. European Journal of Operational Research 258 (2) 607-616 ISSN 0377-2217, https://doi.org/10.1016/j.ejor.2016.08.075

EUROPEAN COMMISSION. 2003. European Union timber regulation. Communication of the commission accessible online at http://ec.europa.eu/environment/forests/timber_regulation.htm

EUROPEAN COMMISSION, 2015. Non-State Actors Participation in Forest Governance, FLEGT and REDD+: Guidelines for grant applicants. Reference: EuropeAid/150699/DH/ACT/Multi

EMERSON, K., NABATCHI, T. and BALOGH, S. 2012. An Integrative Framework for Collaborative Governance. Journal of Public Administration Research and Theory 22(2012) 1-29

FAO. 2014. State of the world's forests 2014 - enhancing the socioeconomic benefits from forests, http://www.fao.org/forestry/sofo/en/

FODER.2017. Foder and the EU-Cameroon VPA: protecting forests, communities and the climate, accessed online 16.07.2019, https://loggingoff.info/wpcontent/uploads/2017/02/eu_cameroon_vpa-2.pdf , 2 pages

FOMETE T. and CERUTTI, P.O. 2008. "Verification in the Forest Sector in Cameroon", In Brown, D., K. Schreckenberg, N. Bird, P. Cerutti, F. Del Gatto, C. Diaw, T. Fomete, C. Luttrell, G Navarro, R. Oberndorf, H. Thiel and A. Wells (Eds) Legal timber: verification and governance in the forestry sector, Overseas Development Institute (ODI), London.

FOX, J.2016. "Scaling Accountability Through Vertically Integrated Civil Society Policy Monitoring and Advocacy," IDS Working Paper, Brighton: Institute for Development Studies/Making All Voices Count, December, 2016.

GARCIA-NETO, A. P., GARCIA-LORENTE, M., INIESTA-ARANDIA, I. and MARTIN-LOPEZ, B. 2013. Mapping forest ecosystem services: from providing units to beneficiaries. Ecosystem Services, 4, 126-138.

GEMMILL, B. and BAMIDELE-IZU.2002. The Role of NGOs and Civil Society in Global Environmental Governance. In D. Esty, and M. Ivanova (Eds). Global Environmental Governance: Options and Opportunities (pp. 77-100). Princeton, NJ: Yale School of Forestry and Environmental Studies.

GLOBAL WITNESS. 2005. A guide to independent forest monitoring. Global Witness Ltd, London, United Kingdom

GODFRAY, H.C.J., BEDDINGTON JR., CRUTE, I.R., HADDAD, L., LAWRENCE, D., MUIR, J.F., PRETTY J., ROBINSON, S., THOMAS, S.M. and TOULMIN, C. 2010. Food security: the challenge of feeding 9 billion people. Science 2010 327:812-818. 
GRANT, A.J., BALRAJ, D. and MAVROPOULOS-VAGELIS, G, 2013. Reflections on network governance in Africa's forestry sector. Natural Resources Forum 37 (2013) 269-279

GREEN, P., WARD, T. and McCONNACHIE, K. 2007. Logging and Legality: Environmental Crime, Civil Society, and the State. Social Justice 34(2 (108)), 94-110.

GREENPEACE NEDERLAND, 2015. CCT'S timber trade from Cameroon to Europe. A test case for EUTR's due diligence requirement. Amsterdam. Retrieved from http://www.greenpeace.nl/Global/nederland/2015/documenten/Bossen/GP_CCT_rapport_sept15_0 3.pdf

GUNNINGHAM, N. 2009. The new collaborative environmental governance: the localisation of regulation. Journal of Law and Society 36(1) 145-166

GUTIERREZ, A.T. and MORGAN, S. 2017. Impediments to fisheries sustainability : comparison of UK and US forest governance networks. Ocean \& Coastal Management 135 (2017) 79-92

HARDIN, R., and BAHUCHET, S. (2011). Concessionary politics: property, patronage, and political rivalry in Central African forest management. Current Anthropology, 52(S3

HALL, J.K., DANEKE, G.A. and LENOX, M.J. 2010. Sustainable development and entrepreneurship: Past contributions and future directions. Journal of Business Venturing 25(5):439-448.

HOARE, A. 2015 Tackling illegal logging and the related trade: Wjat progress and where next? Chatham House Report accessible at https://www.chathamhouse.org/sites/default/files/publications/research/20150715IllegalLoggingHo $\underline{\text { areFinal.pdf }}$

HUMPHREYS, D. 2009. Environmental and ecological citizenship in civil society. The International Spectator. 44(1) 171-183

HUMPHREYS, D. (2012). Logjam: Deforestation and the crisis of global governance. Routledge.

Independent forest monitoring fund (2018) Projects and Programmes, https://www.forestfund.or.id/en/about-us (accessed 18/09/2018)

INTERPOL 2016. Uncovering the Risks of Corruption in the Forestry Sector. Available online at: https://www.interpol.int/.../Uncovering-the-Risks-of-Corruption-in-the-Forestry-Sector. Accessed 11.08.2018

KARSENTY, A., DRIGO, I.G., PIKETTY, M-GA and SINGER, B. 2008. Regulating industrial forest concessions in Central Africa and South America. Forest Ecology and Management 256 (2008) 1498-1508 http://rstb.royalsocietypublishing.org/content/368/1625/20120300.short

KARSENTY, A and ONGOLO, S. 2012. Can fragile states decide to reduce their deforestation? The inappropriate use of the theory of incentives with respect to the REDD+ mechanism. Forest Policy and Economics 18(2012) 38-45 
KLIJN, E.H and KOPPENJAN J.F.M. 2012. Governance network theory: past, present and future. Policy and Politics 40(4) 187-206

KLIJN, E.H and KOPPENJAN J.F.M. 2014. Complexity in governance network theory. Complexity, Governance \& Networks 1(1) 61-70. doi: 10.7564/14-CGN8

KOPPENJAN J.F.M and KLIJN, E.H. 2004. Managing Uncertainties in Networks A network approach to problem solving and decision making. Routledge Taylor \& Francis Group, London and New York.

KOSSMAN, C.M., BEHAGEL, J.H. and BAILEY, M. 2016. Action and inertia in collaborative governance. Marine Policy 72(2016) 21-30

KOUETCHUA, C. 2018. The Ministry of Forests and Wildlife fines the company Oye et Compagnie following a SNOIE denunciation report for illegal logging, accessed 16.07.2019 at https://cidt.org.uk/le-ministere-desforets-frappe-dune-amende-lentreprise-oye-et-compagnie-epinglee-dans-un-rapport-de-denonciation-dusnoie-pour-exploitation-forestiere-illegale/

LINDAHL, B.K., SANSTROM, C. and STENS, A. 2017. Alternative pathways to sustainability? Comparing forest governance models. Forest Policy and Economics 77(April 2017) 69-78

MAYAUX, P., PEKEL, J-F., DESCLEE, B., DONNAY, F., LUPI, A., ACHARD, F., CLERICI, M., BOBERT, C., BRINK, A., NASI, R and BELWARD, A. 2013. State and evolution of the African rainforests between 1990 and 2010. Philosophical Transactions of the Royal Society B 368:

20120300; DOI: 10.1098/rstb.2012.0300

MEGEVAND, C., MONSIEUR, A., HOURTICA, J., TOLLENS, E., WEHKAMP, J. and DULAL, H. 2013. Deforestation trends in the Congo Basin: reconciling economic growth and forest protection Working Paper, The World Bank (2013) http://www.zaragoza.es/contenidos/medioambiente/onu/newsletter15/970-eng.pdf

MULATA, K.A., MORA, B., KOOISTRA, L. and HEROLD, M. 2017. Biodiversity Monitoring in Changing Tropical Forests: A Review of Approaches and New Opportunities. Remote Sensing 9(10) 1059

NASI, R., TABER, A., VAN VLIET, N. 2011. Empty forests, empty stomachs? Bushmeat and livelihoods in the Congo and Amazon Basins. International Forestry Review 13(3) 355-368

NASI, R., BILLAND, A. and VLIET, V. 2012. Managing for timber and biodiversity in the Congo Basin Forest. Ecology and Management 268 (2012) 103-111

ONGOLO, S and KARESENTY, A. 2015. The politics of forestland use in a cunning government: lessons from contemporary forest governance reforms. International Forestry Review 17(2) 1-15

OSTROM, E., 2003. The commons in the new millennium. In: Dolsak, N., Ostrom, E. (Eds.), Challenges and Adaptation. The MIT Press, Cambridge, Massachusetts.

OVERDEVEST, C and RICKENBACH, M. G. 2006. Forest certification and institutional governance: an empirical study of forest stewardship council certificate holders in the United States. Forest Policy and Economics 9(1): 93-102.

RAINFOREST FOUNDATION UK, 2019. Real time forest monitoring empowering communities, preventing illegalities, protecting forests, accessed online 16.07.2019, https://www.rainforestfoundationuk.org/media.ashx/real-time-monitoring-2019.pdf , 11 pages 
RHODES, R.A.W. 1996 The New Governance: Governing without Government. Political Science 44(4) 652-667

SCHURE, J., LEVANG, P. and WIERSUM, K. F. 2014. Producing woodfuel for urban centers in the Democratic Republic of Congo: a path out of poverty for rural households?. World Development, 64, S80-S90.

TEGEGNE, Y. T., LINDER, M., FOBISSUE, K. and KANNINEN, M. 2016. Evolution of drivers of deforestation and forest degradation in the Congo Basin forests: Exploring possible policy options to address forest loss. Land use policy, 51, 312-324.

TEGTMEYER, R., JOHNSON, A., RASARELY, E., BURREN, C., ROBINSON, D., BAUERT, M. and SORG, J-P. 2010. Independent Forest Monitoring Madagascar. Madagascar Conservation and Development 5(1) 64-71.

TSANGA, R., LESCUYER, G. and CERUTTI, P.O. 2014. What is the role for forest certification in improving relationships between logging companies and communities? lessons from FSC in Cameroon. International Forestry Review 16(1): 14-22

TRUBEK, D. M. and TRUBEK, L.G. 2007. New Governance \& Legal Regulation: Complementarity, Rivalry, and Transformation. Columbia Journal of European Law, Summer 2007; Univ. of Wisconsin Legal Studies Research Paper No. 1047. Available at SSRN: https://ssrn.com/abstract $=988065$

SOMORIN, A.O., VISSEREN-HAMAKERS, I.J., ARTS, B', SONWA, D.J. and TIANI, A.M.2013. REDD+ strategy in Cameroon: Actors, institutions and governance. Environmental Sciences and Policy 35(2014) 87-97

SUNDSTROM, 1. 2016. Understanding illegality and corruption in forests governance. Journal of Environmental Management 181(2016): 779-790

U4 BRIEF, 2010. Overview of corruption and anti-corruption in the Democratic Republic of Congo (DRC). https://www.u4.no/publications/overview-of-corruption-and-anti-corruption-in-the-drc.pdf

VATN, A and VEDELD, O.P. 2013. National governance structures for REDD+. Global Environmental Change 23 (2013) 422-432

WHITE, M.D. and MARSH, E.E. 2006. Content Analysis: A Flexible Methodology. Library Trends, 55 (1) Summer 2006 ("Research Methods," edited by Lynda M. Baker) 22-45

WORLD BANK, 2016. Strengthening forest law enforcement and governance: addressing a systemic constraint to sustainable development. Report No. 36638-GLB, August 2006.

World Commission on Forests and Sustainable Development. 1987. Our forests. Accessible online at www.iisd.org/pdf/wcfsdsummary.pdf

YOUNG D. W. 2007. Independent forest monitoring: seven years on. International Forestry Review 9(1), 563-574 
YOUNG D. W. 2016. Independent forest monitoring in Africa 2016 update. Accessible at 2016 update independent forest monitoring in africa - FLEGT.org 